\title{
PROGRAM KEMITRAAN BAGI KELOMPOK GURU DAN SISWA SEKOLAH DASAR INKLUSI DIMIT AR-ROIHAN LAWANG DAN SDN 5 BEDALI LAWANG MALANG
}

\author{
Amin Zakaria'), Heny Nurmayunita'2), Riki Ristanto ${ }^{3)}$ \\ 1,2,3)Program Studi Keperawatan Poltekkes RS dr. Soepraoen Kesdam V/Brawijaya Malang \\ e-mail: dhilahanin88@gmail.com
}

\begin{abstract}
Abstrak
Guru selaku pengganti orang tua siswa bertanggungjawab terhadap kebutuhan anak didiknya disekolah, sekaligus menjamin keselamatan peserta didik ketika berada disekolah. Para guru harus menyadari karakteristik fisik, emosi, perilaku masing - masing siswa yang dapat menimbulkan kondisi kegawatdaruratan serta waspada terhadap faktor-faktor lingkungan yang mengancam keamanan anak (Soetjiningsih, 2008). Kedua mitra menyelenggarakan sekolah inklusi yang tentunya memiliki resiko lebih tinggi terjadi masalah kesehatan dibanding sekolah biasa. Pelaksanaan pembelajaran inklusi, sekolah harus menyediakan sistem layanan pendidikan yang disesuaikan dengan kebutuhan ATBK dan ABK melalui adaptasi kurikulum, pembelajaran, penilaian, dan sarana prasarananya (pelayanan UKS). UKS yang ada pada kedua mitra belum memadai, baik aspek SDM, sarana prasarana, program dan kegiatannya. Para guru belum sepenuhnya memiliki pengetahuan, kemauan, serta ketrampilan yang cukup jika sewaktu-waktu terjadi cedera dan kondisi kegawatdaruratan disekolah. Belum ada fasilitas untuk menjadi sumber belajar secara berkelanjutan bagi pengelola UKS dalam mengembangkan kemampuan untuk mengelola UKS berbasis inklusi, dan pertolongan pertama cedera dan kondisi kegawatdaruratan siswa disekolah. Tujuan kegiatan pengabdian ini adalah untuk meningkatkan pengetahuan, kemauan dan ketrampilan mitra tentang managemen dan pengelolaan UKS berbasis inklusi, penanganan pertama pada cedera dan kegawatdaruratan di kedua mitra. Metode yang digunakan pelatihan, pendampingan, pengadaan obat - obatan dan peralatan UKS bagi kedua mitra. Hasil yang dicapai terjadinya peningkatan pengetahuan melalui kegiatan pre-post test, peran serta seluruh peserta dan panitia $100 \%$ kehadirannya, pembuatan modul dan poster tentang protap sistem pelayanan UKS, protap pertolongan pertama pada cedera, dan kegawatdaruratan disekolah. Publikasi jurnal online nasional, media cetak jawa poas koran radar malang terbit pada tanggal 3 Mei 2018 hal. 12, dan memambahan jenis dan jumlah sarana prasarana UKS dan Tim Tanggap Darurat atau dokter kecil.
\end{abstract}

Kata Kunci : Sekolah Dasar, Inklusi, UKS, Penangan Cedera, dan Kegawatdaruratan.

\section{PENDAHULUAN}

Analisa Situasi, Sekolah Dasar Negeri (SDN) Bedali 05 dan Madarasah Ibtidaiyah Terpadu (MIT) Ar- Roihan Lawang merupakan sekolah dasar yang menyelenggarakan program sekolah inklusi, yaitu sistem pembelajarannya digabung antara Anak Berkebutuhan Khusus (ABK) dan Anak Tidak Berkebutuhan Khusus (ATBK).

Tabel 1, Jumlah Siswa ABK di SDN Bedali 05 dan MIT Ar-Roihan Lawang

\begin{tabular}{|c|l|c|c|}
\hline No & \multicolumn{1}{|c|}{ Jenis ABK } & $\begin{array}{c}\text { SDN } \\
\text { Bedali 5 }\end{array}$ & $\begin{array}{c}\text { MIT } \\
\text { Ar-Roihan }\end{array}$ \\
\hline 1. & Tuna Rungu & 6 & 2 \\
\hline 2. & Tuna Daksa & 2 & 6 \\
\hline 3. & Tuna Laras & 0 & 1 \\
\hline
\end{tabular}

\begin{tabular}{|c|c|c|c|}
\hline No & Jenis ABK & $\begin{array}{c}\text { SDN } \\
\text { Bedali } 5 \\
\end{array}$ & $\begin{array}{c}\text { MIT } \\
\text { Ar-Roihan } \\
\end{array}$ \\
\hline 4. & Lambat Belajar & 8 & 6 \\
\hline 5. & Autis & 3 & 3 \\
\hline 6. & Kesulitan Belajar & 2 & 7 \\
\hline 7. & Hiperaktif & 4 & 11 \\
\hline 8. & $\begin{array}{l}\text { Kelainan Ginjal (Cuci } \\
\text { darah rutin) }\end{array}$ & 2 & 2 \\
\hline 9. & $\begin{array}{l}\text { Lambat belajar + Autis } \\
+ \text { Kelainan jantung } \\
\text { bawaaan (Post } \\
\text { Operasi) }\end{array}$ & 2 & 2 \\
\hline \multirow[t]{2}{*}{10.} & Autis + Sesak napas & 3 & 4 \\
\hline & Total & 32 & 44 \\
\hline
\end{tabular}


Para guru/pendidik yang bertugas mengawasi siswa belum memiliki pengetahuan serta ketrampilan yang cukup untuk menangani jika sewaktu-waktu terjadi kondisi kegawatdaruratan/ cedera. Sebagai contoh kejadian tidak diinginkan yang pernah terjadi di SDN Bedali 05 maupun di MIT Ar-Roihan pada tiga tahun terakhir, yaitu: adanya siswa yang tersedak cilok yang menyebabkan siswa meninggal, siswa kejang epilepsi sampai meninggal, kejadian siswa yang mengalami sesak nafas yang diakibatkan kekambuhan penyakit asmanya, adanya kejadian sianosis/kebiruan karena kelainan darah dan kelainan jantung yang diderita siswa, adanya kejadian patah tulang dan cedera lain yang diakibatkan jatuh atau terkena benda tajam saat proses belajar atau bermain.

Selama ini kegawatdaruratan seperti jatuh patah tulang, sesak napas, kejang epilepsi dan sianosis/kebiruan gangguan jantung penangananya langsung dirujuk kepelayanan kesehatan tanpa diberikan penaganan pertama kegawatdaruratan untuk penyelamatan jiwa dan tidak disertakan alat pertolongan utama seperti oksigen. Penanganan kegawatdaruratan dilingkungan sekolah semestinya harus ada pertolongan pertama untuk penyelamatan jiwa anak baru dilakukan rujukan kepelayanan kesehatan dengan peralatan yang memadai. Hal ini dikarenakan pengelola UKS jumlah kurang, tidak memiliki kemampuan dan keterampilan, tidak memiliki sarana prasarana penanganan kegawatdaruratan dilingkungan sekolah. Pertolongan pertama yang tidak tepat dapat berakibat fatal berupa kematian.

Hal ini tentunya perlu mendapat perhatian yang serius, mengingat para orangtua wali khususnya dan semua pihak pada umumnya tidak menginginkan risiko-risiko injury dan kematian tersebut terjadi. Untuk itu, muatan ketrampilan penanganan cedera dan penanganan kegawatdaruratan perlu diberikan kepada para guru/pendidik di SDN Bedali 05 danMIT Ar-Roihan, hal tersebut dikarenakan banyaknya fasilitas bermain secara out door yang belum memenuhi standar, adanya peserta didik ABK dengan masalah kesehatan khusus yang tentunya membutuhkan adanya perhatian yang sungguh sungguh.
Berikut data SDM guru yang ada di kedua lembaga.

Tabel 2, Data SDM Guru

\begin{tabular}{|l|c|c|}
\hline \multicolumn{1}{|c|}{ Uraian } & $\begin{array}{c}\text { SDN Bedali } \\
\mathbf{0 5}\end{array}$ & MIT Ar-Roihan \\
\hline Jumlah SDM guru & 9 & 90 orang \\
\hline Jumlah pengelola UKS & 1 & 2 \\
\hline $\begin{array}{l}\text { Latar belakang } \\
\text { pendidikan guru dari } \\
\text { ilmu kesehatan }\end{array}$ & - & - \\
\hline $\begin{array}{l}\text { Sarana/ media untuk } \\
\text { belajar mandiri bagi } \\
\text { guru } \\
\text { tentang kesehatan di } \\
\text { sekolah }\end{array}$ & $\begin{array}{c}\text { Tidak } \\
\text { tersedia }\end{array}$ & Tidak tersedia \\
\hline $\begin{array}{l}\text { Pelatihan bagi guru } \\
\text { tentang kesehatan } \\
\text { terutama } \\
\text { ketrampilan pertolongan } \\
\text { pertama pada cedera) }\end{array}$ & Belum & Belum pernah \\
\hline $\begin{array}{l}\text { Pelatihan bagi guru } \\
\text { tentang pengelolaan } \\
\text { UKS }\end{array}$ & Belum & Belum pernah \\
\hline
\end{tabular}

Masalah dan Solusi, Melalui kegiatan pengabdian ini, target dan luaran yang ingin dicapai adalah sebagai berikut:

Tabel 2.1 Masalah dan Solusi

\begin{tabular}{|c|c|}
\hline MASALAH & SOLUSI \\
\hline $\begin{array}{l}\text { SDM } \\
\text { Kurangnya pengetahuan dar } \\
\text { keterampilan guru } \\
\text { tentang: manajemen } \\
\text { pengelolaan UKS, } \\
\text { penanganan cedera dan } \\
\text { penanganan } \\
\text { kegawatdaruratan siswa di } \\
\text { sekolah. Dan Tidak } \\
\text { adanya tim khusus } \\
\text { Penanganan cedera dan } \\
\text { kondisi kegawatdaruratan. }\end{array}$ & $\begin{array}{l}\text { Seminar dan Pelatihan } \\
\text { tentang manajemen dan } \\
\text { pengelolaan UKS yang } \\
\text { berbasis inklusi, } \\
\text { penanganan cedera bagi } \\
\text { kelompok guru dan siswa } \\
\text { dan pelatihan basic life } \\
\text { support. Pembentukan tim } \\
\text { dokter kecil bagi siswa } \\
\text { disekolah. }\end{array}$ \\
\hline $\begin{array}{l}\text { Sarana dan Prasarana } \\
\text { Kurangjenis, jumlah obat } \\
\text { obatan, peralatan UKS, dan } \\
\text { Kuranya sarana dan } \\
\text { prasarana UKS }\end{array}$ & $\begin{array}{l}\text { Pengadaan jenis, jumlah obat } \\
\text { - obatan, peralatan UKS, dan } \\
\text { Kuranya sarana dan prasaran } \\
\text { UKS }\end{array}$ \\
\hline $\begin{array}{l}\text { Media Belajar } \\
\text { Tidak adanya media belajar } \\
\text { bagi kelompok } \\
\text { guru/pendidik dan siswa } \\
\text { untuk meningkatkan } \\
\text { kompetensinya secara } \\
\text { berkelanjutan dalam }\end{array}$ & $\begin{array}{l}\text { Pengadaan modul } \\
\text { manajemen dan } \\
\text { pengelolaan UKS berbasis } \\
\text { inklusi. } \\
\text { tentang penanganan cedera } \\
\text { dan kegawatdaruratan siswa } \\
\text { di sekolah. Pengadaan protap }\end{array}$ \\
\hline
\end{tabular}




\section{METODE KEGIATAN}

Metode pelaksanaan yang digunakan adalah pelatihan, pendampingan, pengadaan obat - obatan serta peralatan UKS bagi kedua mitra dan pemberian modul manajemen dan pengelolaan UKS berbasis inklusi, modul penanganan pertama cedera, dan modul penanganan kondisi kegawatdaruratan disekolah.

Kegiatan seminar dan pelatihan dilaksanakan sebanyak tiga kali, yaitu: 1) seminar dan pelatihan tentang pengembangan manajemen dan pengelolaan UKS berbasis inklusi, 2) penanganan pertama cedera, dan 3) penanganan kondisi kegawatdaruratan. Masing-masing kegiatan akan diawali dengan kegiatan seminar untuk menyampaikan materi/teori dan berikutnya dilanjut dengan kegiatan untuk meningkatkan keterampilan/kemampuan pada topik yang dimaksud. Diperkirakan waktu untuk satu kegiatan seminar dan pelatihan dibutuhkan waktu masing - masing 2 hari berkisar $\pm 10 \mathrm{jam} / \mathrm{hari}$. Total kegiatan seminar dan pelatihan yaitu sekitrar 6 hari dan 60 Jam. Untuk proses evaluasi keberhasilan seminar, maka direncanakan pelaksanaan pretest dan post test yang bertujuan untuk mengukur peningkatan pengetahuan sebelum dan sesudah dilakukan seminar/pemberian materi. Evaluasi keterampilan dan kemampuan kelompok guru dan siswa dengan metode observasi, menggunakan cek list dengan teknik memberikan kesempatan untuk simulasi keterampilan oleh masing-masing peserta dari kedua mitra. Langkah ketiga setelah diberikan pelatihan yaitu pembentukan tim tanggap darurat penanganan cedera dan kegawatdaruratan pada kelompok guru dan siswa (tim dokter kecil).

Sarana Prasarana Pendukung UKS, solusi yang disepakati adalah Penambahan sarana dan prasarana pendukung UKS untuk pertolongan pertama kejadian cedera di sekolah, untuk pertolongan kegawatdaruratan di sekolah.

Pembuatan sarana belajar mandiri: Pengadaan protap tentang prosedur pelayanan UKS, sistem rujukan, dan prosedur pertolongan kegawatdaruratan. Pembuatan media belajar mandiri yaitu : modul manajemen dan pengelolaan UKS berbasis inklusi, modul penanganan pertama cedera, dan modul penanganan kondisi kegawatdaruratan disekolah.
Pendampingan oleh tim akan dilaksanakan selama kegiatan PKM kepada kedua mitra, baik secara terstruktur maupun tidak tersetruktur. Sebagai contoh pendampingan dalam menyusun program UKS, menata sarana dan prasarana UKS, pendampingan langsung saat penaganan kasus cedera dan kegawatdaruratan disekolah, dan seterusnya.

Partisipasi mitra dalam pelaksanaan program pengabdian masyarakat ini yaitu berupa partisipasi peserta dari masing-masing mitra dan penyediaan sarana dan prasarana pelaksanaan seminar dan pelatihan. Sarana dan prasarana tersebut diantaranya adalah: tempat untuk pelaksanaan seminar dan pelatihan, LCD, layar untuk LCD, sound system, karpet dll. Untuk sarana dan prasarana praktik, sepenuhnya akan disiapkan oleh tim pengabdian masyarakat.

Upaya keberlanjutan program pengabdian masyarakat ini diwujudkan dengan menjadikan kedua mitra sebagai sekolah binaan dalam bidang kesehatan. Sebagai sasaran umum adalah kegiatan pengembangan UKS, dengan salah satu program unggulannya adalah terbentuknya satgas dokter kecil, dimana satgas tersebut terdiri dari siswa dan guru yang sudah dilatih untuk penanganan cedera dan kondisi kegawatdaruratan pada anak. Diharapkan dengan adanya tim tanggap darurat pada kelompok guru dan tim dokter kecil yang sudah terlatih, dapat melakukan kaderisasi pada masing-masing lembaga pendidikan mitra.
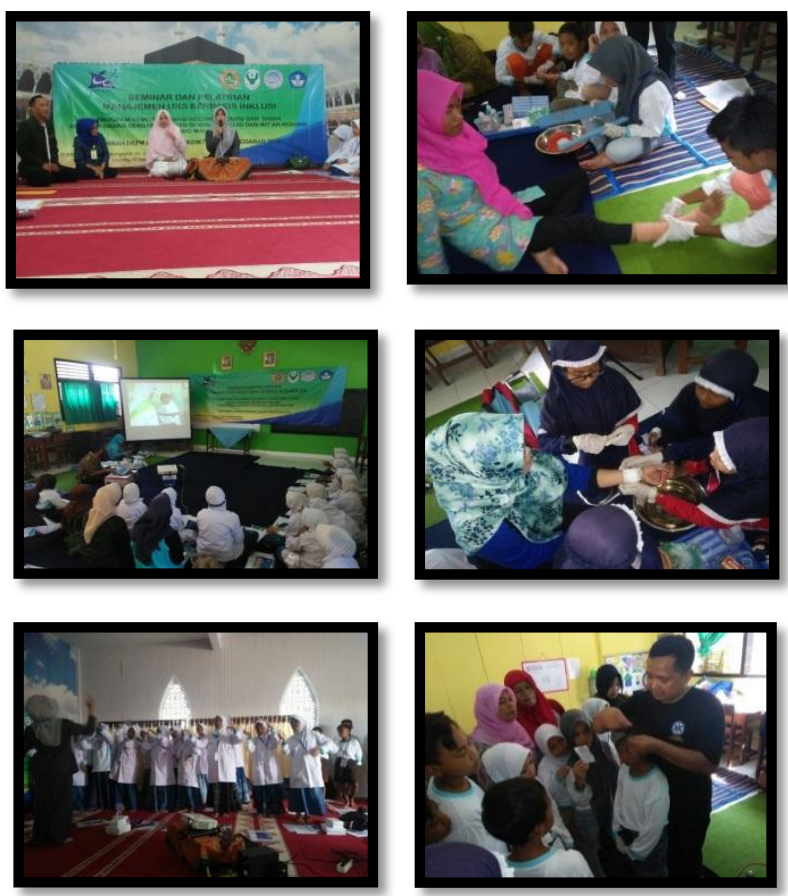

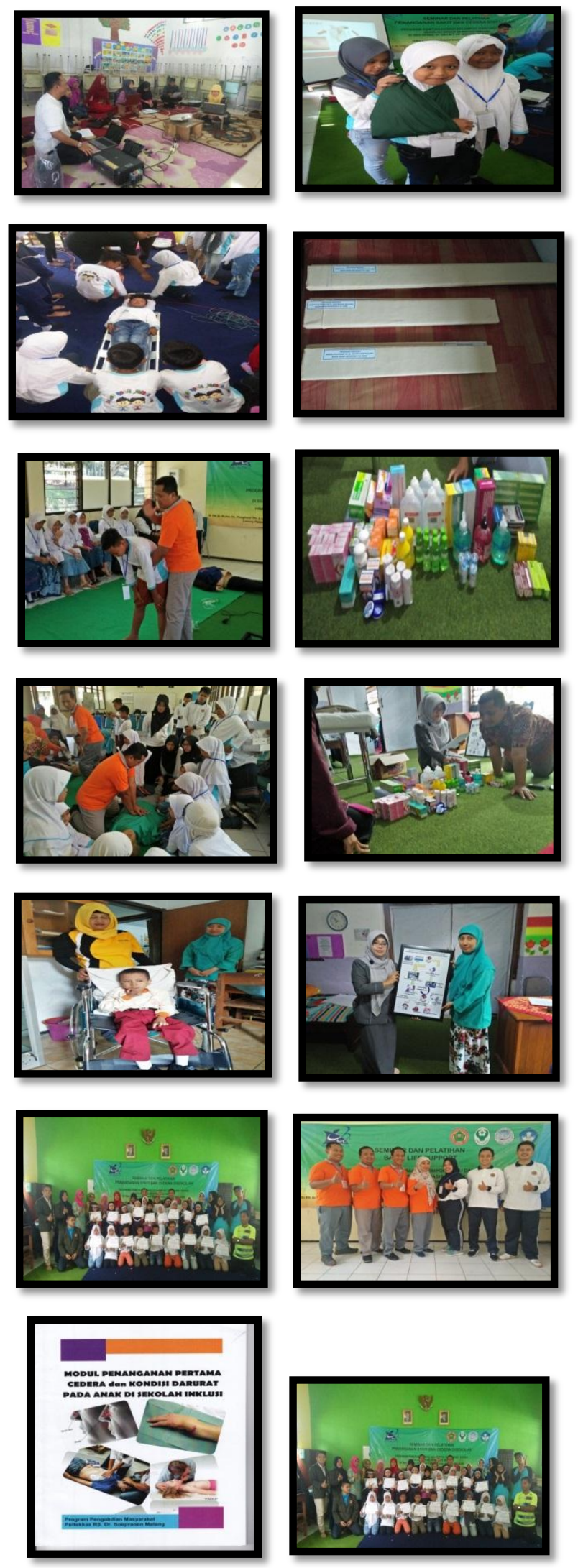

\section{HASIL DAN PEMBAHASAN}

Kegiatan pengabdian kepada masyarakat dengan Program Kemitraan Bagi Kelompok Guru dan Siswa Sekolah Dasar Berbasis Inklusi Di SDN 05 Bedali Dan Madarasah Ibtidaiyah Terpadu (MIT) Ar-Roihan Lawang Malang dimulai pada 7 Maret - 30 Oktober 2018. Fokus kegiatan dilaksanakan didua tempat yaitu mitra pertama MIT Ar-Roihan Lawang Malang dan mitra kedua diSDN 5 Bedali Lawang Malang. Satu kegiatan pelatihan yaitu pelatihan Basic Live Suport (BLS) bertempat diSLB Pembina C Malang, dikarenakan permintaan pengelola UKS diSLB Pembina $\mathrm{C}$ Malang. Menimbang asas meningkatkan pemanfaatan kegiatan pelatihan, kedua mitra memiliki karakteristik yang sama (ada siswa $\mathrm{ABK}$ ), dan keinginan belajar tentang pengelolaan UKS oleh kedua mitra di UKS diSLB Pembina C Malang dengan metode studi tour. UKS SLB Pembina C Malang predikat Juara 1 Tingkat Jawa Timur tahun 2018 dan tahun ini mewakili Jawa Timur mengikuti lomba UKS tingkat nasional.

Sejak dimulainya kegiatan pada bulan Maret sampai dengan September 2018, beberapa kegiatan yang sudah dilakukan adalah sebagai berikut:

\section{Sosialisasi dan Persiapan program IbM}

Persiapan kegiatan dilaksanakan mulai tanggal 7 Maret 2018, dengan tujuan kegiatan adalah 1) mensosialisasikan proposal program pengabdian masyarakat tim dosen Poltekkes RS dr. Soepraoen yang disetujui oleh DRPM Ristekdikti tahun pelaksanaan 2018, 2) Program kegiatan pengabdian dosen yang akan dilaksanakan, 3) Peran pengabdi dan kedua mitra, dan 4) target hasil dan luaran kegiatan. Hasil kegiatan: 1) Kedua mitra memahami rencana program IbM, 2) merespon dengan sangat positif dan siap mendukung seluruh program, 3) Disepakati rencana rapat pertama tim pengabdi dosen dan pengelola UKS dari kedua mitra, pada: 16 Maret 2018. Rapat didapatkan hasil: 1) Jadual program kegiatan abdimas, 2) Struktur anggota panitia Abdimas, 3) Pembuatan surat tugas untuk menjadi panitia abdimas, dan 4) Surat keputusan kepala sekolah tentang pengelola UKS dan dokter kecil, 5) Peran mitra adalah menyiapkan tempat, sound system, LCD, layar, peserta pelatihan, membantu 
selama kegiatan seminar dan pelatihan dilaksanakan, dan 6) Peran tim abdimas menyiapkan ATK, materi pelatihan, sertifikat, konsumsi dan akomodasi, pemateri, honor kegiatan, dll.

\section{Pelatihan Managemen UKS Berbasis Inklusi}

Kegiatan pelatihan dilaksanakan pada tanggal 6 - 7 April 2018 bertempat diMIT Ar -Roihan Lawang Malang. Peserta yang terlibat sebanyak 50 Orang, terdiri dari: 13 orang panitia, 10 guru pengelola UKS, 25 orang siswa tim dokter kecil, dan pemateri 2 orang. Persiapan pemateri, tempat, sound system, LCD, layar, peserta pelatihan, ATK, sertifikat, konsumsi dan akomodasi, seragam dokter kecil, dll. Kegiatan ini pada hari pertama diawali dengan pembukaan dan pelantikan dokter kecil oleh masing - masing kepala sekolah, dilanjutkan materi tentang sekolah inklusi dan permasalahan kesehatan, managemen UKS berbasis inklusi, dokter kecil, kegawatdaruratan disekolah. Pada hari kedua materi tentang: 1) Organsisai UKS inklusi, 2) pembuatan rencana program UKS Inklusi, 3) strategi pelaksanaan UKS, 4) monitoring dan evaluasi program UKS. Untuk menilai keberhasilan tindakan aspek pengetahuan dan keterampilan diukur dengan intrument soal metode test prae dan post kegiatan pelatihan.

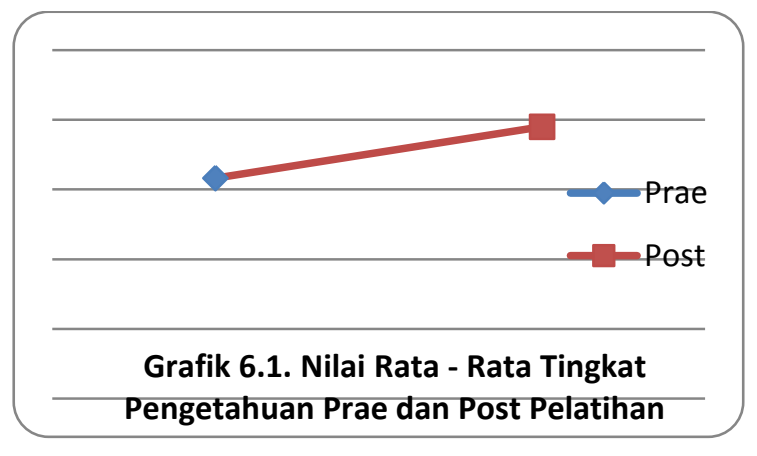

Berdasarkan grafik 6.1 didapatkan bahwa adanya peningkatan nilai rata - rata kelas tingkat pengetahuan peserta pelatihan. Pada prae test nilai rata - rata kelas 63 katagori cukup dan post test menjadi 78 dengan katagori baik, terjadi peningkatan 15 skore. Pengetahuan tersebut meliputi pokok bahasan sekolah inklusi dan permasalahan kesehatan, managemen UKS berbasis inklusi, dokter kecil, kegawatdaruratan disekolah, Organsisai UKS inklusi, pembuatan rencana program UKS Inklusi, strategi pelaksanaan UKS, dan monitoring dan evaluasi program UKS.

Pada aspek sikap yaitu kehadiran panitia dan peserta $100 \%$ kepala sekolah kedua mitra secara bergantian juga hadir membuka - menutup acara, melantik dokter kecil, mendampingi kegiatan sampai selesai dan motivasi peserta sangat tinggi. Dukungan kedua mitra dalam bentuk tenaga peserta, panitia, tempat, sarana dan prasarana sangat baik.

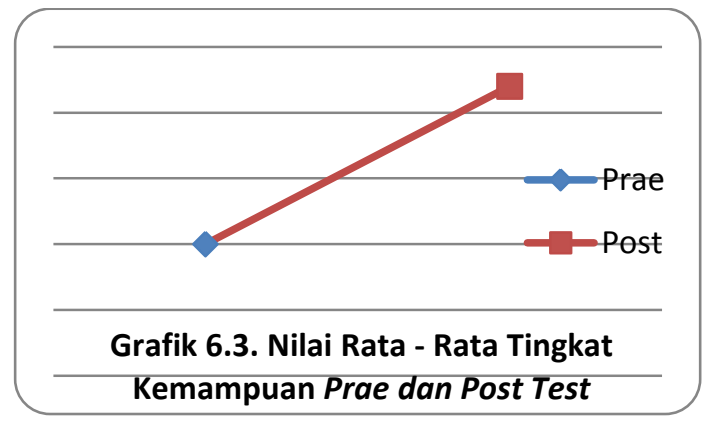

Berdasarkan grafik 6.3 didapatkan hasil bahwa terjadi peningkatan kemampuan peserta pelatihan dalam hal membuat struktur oganisasi, membuat rencana kerja UKS tahunan, membuat pelaporan UKS antara prae test didapatkan nilai rata - rata kelas 70 dengan katagori baik dan post test nilai rata - rata menjadi 82 dengan katagori sangat baik.

Untuk menunjang kebutuhan belajar secara berkelanjutan bagi para pengelola UKS, dokter kecil dan siswa diberikan modul tentang UKS berbasis Inklusi. Dengan keberadaaan modul ini bisa dijadikan referensi/rujukan bagi pemangku kepentingan UKS dalam meneglola UKS secara berkelanjutan walaupun kegiatan abdimas dosen sudah selesai. Untuk meningkatkan eksistensi UKS dikedua mitra maka akan direncanakan program pendampingan UKS oleh dosen dalam kegiatan pengabdian masyarakat dari tahun ketahun.

\section{Pelatihan Penaganan Sakit dan Cedera di Sekolah}

Kegiatan pelatihan dilaksanakan pada tanggal 20 - 21 April 2018, Tim yang terlibat seluruhnya adalah 47 orang dengan rincian: panitia 12 orang, peserta guru pengelola UKS sebanyak 10 orang, dan 25 siswa tim dokter kecil. Materi pelatihan peran dokter kecil, konsep sakit dan penanganan, cara 
pertolongan pertama pada kejadian cedera dan kegawatan disekolah.

Metode pelatihannya adalah demonstrasi dengan peserta dibagi menjadi empat kelompok dan tiap kelompok terdiri dari dua orang pengelola UKS, 5 dokter kecil dan didampingi oleh pemateri dan mahasiswa yang membantu kegiatan pelatihan. Masing - masing peserta memiliki kesempatan untuk mempraktikan secara langsung dari setiap keterampilan yang diajarkan. Sebelum kegiatan pelatihan dilakukan prae test dan post test setelahnya.

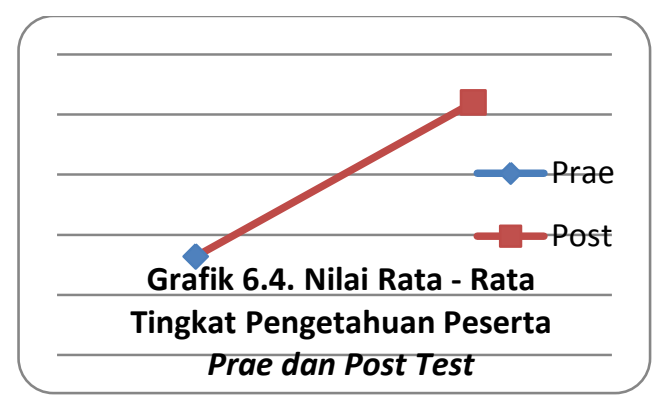

Berdasarkan grafik 6.4 didapatkan hasil bahwa nilai rata - rata kelas terjadi peningkatan antara prae test dan post test. Prae test nilai rata - rata kelas 68 dengan katagori cukup dan post test menjadi 81 dengan katagori sangat baik. Pengetahuan tersebut meliputi peengetahuan para guru dan siswa tentang materi peran dokter kecil, penanganan sakit dan cedera disekolah apa peran dokter kecil, mengenali sakit yang sering terjadi disekolah, diantaranya : panas/demam, pusing/ nyeri kepala, sakit perut, mual dan muntah, diare, batuk dan pilek, cacar air, herpes, mata merah, tantrum, pingsan, hiperaktif, autisme.

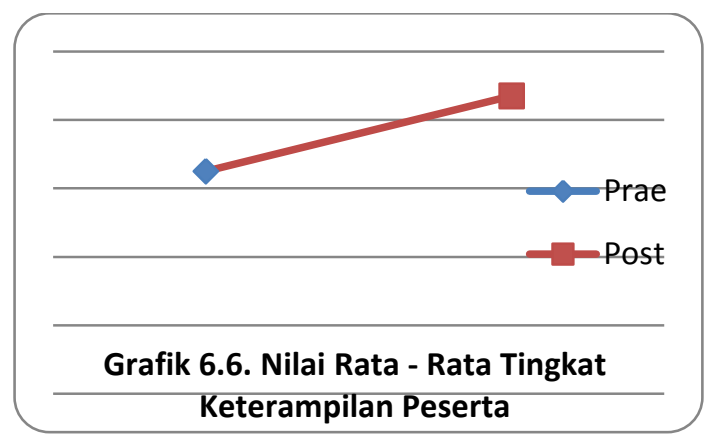

Berdasarkan Grafik 6.6 didapatkan hasil bahwa terjadi peningkatan kemampuan keterampilan peserta antara sebelum dan sesudah pelatihan, dengan nilai rata - rata kelas prae test 65 dengan katagori cukup dan post test 87 dengan katagori sangat baik. Nilai rata - rata keterampilan para peserta meliputi keterampilan mengukur BB, TB, mengukur suhu tubuh menggunakan termometer, tekanan darah, memberikan kompres, cara merawat luka, menangani mimisan dan perdarahan, teknik pembebatan luka, cara penanganan dislokasi dan patah tulang, teknik pembidaian, dan cara memberikan pertolongan pada penderita pingsan.

Pada aspek sikap peserta sangat antusias sekali karena pelatihan ini tidak pernah dilakukan dan materi sangat bermanfaat pada kegiatan sehari - hari. Kehadiran panitia dan peserta $100 \%$ kepala sekolah juga hadir membuka acara. Dukungan mitra dalam bentuk tenaga peserta, panitia, tempat, sarana dan prasarana sangat baik.

\section{Pembuatan Modul Pembelajaran}

Untuk menunjang kebutuhan belajar secara berkelanjutan bagi para pengelola UKS, dokter kecil dan siswa diberikan modul tentang penaganan sakit dan cedera disekolah inklusi. Keberadaan modul ini bisa dijadikan referensi/rujukan bagi pemangku kepentingan UKS untuk selalu meningkatkan kemampuannya dalam merawat siswa disekolah walaupun kegiatan abdimas dosen sudah selesai. Untuk meningkatkan kemampuan pelayanannya para pengelola UKS dikedua mitra maka akan direncanakan program pendampingan UKS oleh dosen dalam kegiatan pengabdian masyarakat dari tahun ketahun.

\section{Pelatihan Basic Life Support Bagi Para Guru dan Siswa}

Kegiatan ini dilaksanakan pada tanggal 2 Mei 2018, Peserta pelatihan BLS adalah para guru dan siswa dari kedua mitra dan guru dan siswa dari SLB sehingga total jumlah peserta adalah 40 orang. Kegiatan pelatihan ini dimulai jam 08.00 16.00 WIB. Materi pelatihan meliputi cara memberikan pertolongan pertama pada: penderita pinsan, penderita anak tersedak, mengalami henti napas, henti jantung, dan bantuan hidup dasar resusitasi dan pijat jantung.

Metode pemberian materi dengan demonstrasi secara langsung pada manekin/pantom resusitasi 
dan pijat jantung. Manekin berjumlah 3 buah pantom sehingga peserta dibagi menjadi tiga kelompok, dan setiap kelompok terdiri dari siswa dan guru pengelola UKS didampingi oleh satu orang trainer dan satu orang mahasiswa. Pertama seorang trainer akan meberikan contoh dengan mendemonstrasikan secara langsung kemudian masing - masing kelompok akan mempraktikan secara bergantian pada keterampilan yang dimaksud. Sebelum dan sesudah kegiatan pelatihan dilakukan prae dan post test untuk menilai keberhasilan kegiatan pelatihan yang dimaksud.

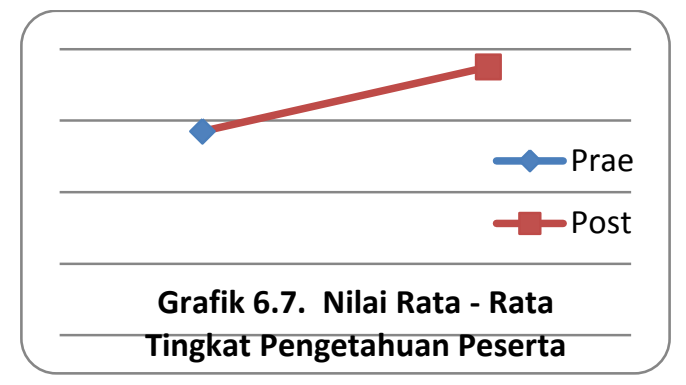

Berdasarkan grafik 6.7 didapatkan bahwa terjadi peningkatan pengetahuan peserta pelatihan tentang Basic Live Support (BLS) yaitu didapatkan nilai rata - rata kelas 57 dengan katagori cukup dan post test nilai rata - rata menjadi 75 dengan katagori baik.

Peserta pelatihan sangat antusias, nara sumber membimbing satu persatu peserta untuk mempraktikkan keterampilan yang diajarkan. Selama kegiatan berlangsung para peserta mendengarkan penjelasan pemateri dan sesekali mengajukan pertanyaan terkait materi tersebut.

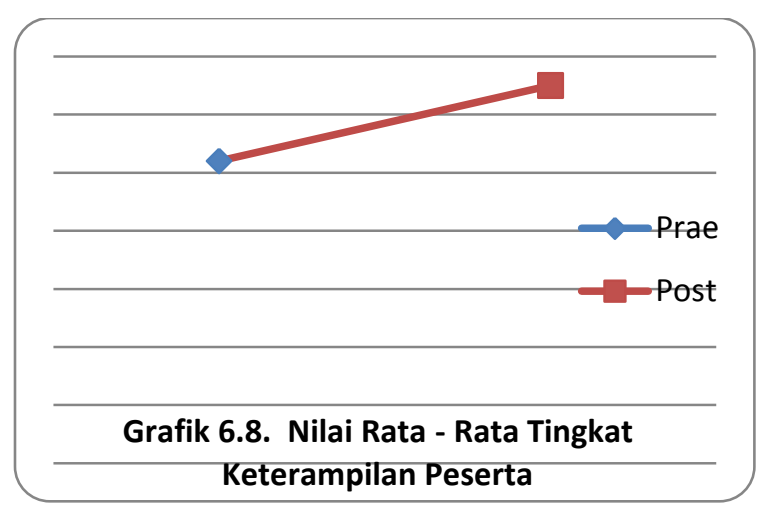

Berdasarkan grafik 6.8 didapatkan bahwa terjadi peningkatan kemampuan/keterampilan peserta pelatihan tentang Basic Live Support (BLS, yaitu didapatkan nilai rata - rata kelas 52 dengan katagori cukup dan post test nilai rata - rata menjadi 65 dengan cukup baik. Keterampilan tersebut meliputi: pertolongan pertama pada penderita tersedak, pertolongan pertama pada henti napas, dan pertolongan pertama pada penderita yang tidak sadar, henti napas dan jantung. Keahlian basic life support ini perlu diasah dan dipratikkan terus menerus agar keterampilan ini tetap dimiliki oleh para guru TK, sehingga perlu dilakukan pendampingan berkelanjutan dari tim untuk mitra agar peserta tidak lupa dengan ilmunya.

Selama kegiatan pelatihan ini, pihak mitra diberi bantuan berupa modul (buku panduan) tentang penanganan kegawadaruratan pada anak disekolah. Selain itu juga diberikan kepada sekolah dari tim pengabdian yaitu SOP (standart operasional prosedur) untuk pertolongan pertama jika terjadi injury pada anak-anak di sekolah. SOP diberikan dalam bentuk cetakan besar $60 \mathrm{~cm} \mathrm{x} 40 \mathrm{~cm}$, terbuat dari bahan poster dalam bingkai akrilik, sehingga dijamin awet dan tahan lama serta desain yang indah. SOP tersebut dipasang pada dinding sekolah (tempat strategis) sehingga mudah dibaca oleh setiap komunitas yang ada di sekolah.

\section{Pengadaan Obat - Obatan, Sarana dan Prasarana UKS}

Kegiatan ini dimulai dengan rapat penetapan kebutuhan Obat - Obatan, Sarana dan Prasarana UKS, dilaksanakan pada tanggal 3 Juli 2018, didapatkan hasil bahwa: 1) standar obat, sarana dan prasarana UKS, 2) Kebutuhan obat - obatan, sarana dan prasarana UKS oleh masing - masing mitra, 3) Musyawarah obat - obatan, sarana dan prasarana UKS yang didukung oleh program IbM/PKM, 4) Penetapan obat - obatan, sarana dan prasarana UKS yang didukung oleh program IbM/PKM, (daftar terlampir).

Kegiatan berikutnya adalah pengadaan barang dilakukan oleh tim abdimas selama kurang lebih dua minggu. Jenis barang yang dibelanjakan meliputi : obat - obatan, alat kesehatan dan mebeler ruang UKS. Obat - obatan seperti penurun panas, penghilang nyeri, obat batuk, obat tetes mata, obat magh, minyak gosok, vicks, cream, refanol, betadine, dan alat - alat kesehatan timbangan, tensi 
meter, stetoskop, termometer, meteran, spalek, kapas, kasa, dll adalah digunakan untuk memberikan pertolongan pertama pada kejadian sakit dan cedera disekolah dan menunjang kegiatan operasional UKS.

Setelah pembelajaan selesai dilaksanakan pelebelan atau memberikan inventaris identitas alat alat, kemudian melakukan pengiriman barang dan serima barang kepada kedua mitra.

Tabel 6.1. Perubahan Kondisi UKS Mitra Pertama MIT Ar Roihan Lawang Malang

\begin{tabular}{|c|c|c|}
\hline \multirow{2}{*}{ SARPRAS } & \multicolumn{2}{|c|}{ PERUBAHAN } \\
\hline & SEBELUM & SESUDAH \\
\hline $\begin{array}{l}\text { Gedung } \\
\text { UKS }\end{array}$ & $\begin{array}{l}\text { Ukuran } 3 \text { X } 3 \text { M, } \\
\text { Menyatu dengan } \\
\text { ruang istirahat } \\
\text { guru dan jauh } \\
\text { dari ruang kelas } \\
\text { siswa. }\end{array}$ & $\begin{array}{l}\text { Pindah ruangan } \\
\text { Ukuran } 6 \text { X } 8 \mathrm{M} \text {, } \\
\text { khusus UKS dan } \\
\text { dekat dengan ruang } \\
\text { kelas siswa, seluruh } \\
\text { lantai diberi karpet } \\
\text { baru bersih cat baru. }\end{array}$ \\
\hline Mebeler & $\begin{array}{l}\text { Tidak memiliki: } \\
\text { tempat tidur, } \\
\text { Meja tulis untuk } \\
\text { kerja, kursi. } \\
\text { Tidak ada almari } \\
\text { obat (Kotak Obat } \\
\text { kecil) }\end{array}$ & $\begin{array}{l}\text { Sudah memiliki dua } \\
\text { tempat tidur, satu } \\
\text { Meja tulis untuk kerja } \\
\text { dan dua kursi. } \\
\text { Sudah memiliki } \\
\text { almari obat }\end{array}$ \\
\hline $\begin{array}{l}\text { Obat - } \\
\text { obatan }\end{array}$ & $\begin{array}{l}\text { Dulu hanya } \\
\text { sedikit dan } \\
\text { terbatas }\end{array}$ & $\begin{array}{l}\text { Sudah lengkap seperti } \\
\text { yang ada didaftar } \\
\text { pembelian baran mitra } \\
1\end{array}$ \\
\hline $\begin{array}{l}\text { Alat - Alat } \\
\text { Kesehatan }\end{array}$ & $\begin{array}{l}\text { Hanya punya } \\
\text { termoter axiler }\end{array}$ & $\begin{array}{l}\text { Timbangan berdiri, } \\
\text { tensi meter, meteran, } \\
\text { termometer, } \\
\text { stetoskop, snelen } \\
\text { chart, dll. }\end{array}$ \\
\hline SDM & $\begin{array}{l}\text { Dua tenaga } \\
\text { pengelola UKS, } \\
\text { Belum punya tim } \\
\text { dokter kecil dan } \\
\text { tim tanggap } \\
\text { darurat, juga } \\
\text { belum pernah } \\
\text { dilatih. }\end{array}$ & $\begin{array}{l}\text { Memiliki lima tenaga } \\
\text { pengelola UKS, } 15 \\
\text { siswa tim dokter kecil } \\
\text { dan tim tanggap } \\
\text { darurat, sudah dilatih. }\end{array}$ \\
\hline
\end{tabular}

Tabel 6.2. Perubahan Kondisi UKS Mitra Kedua SDN 5 Bedali Lawang Malang

\begin{tabular}{|l|l|l|}
\hline \multirow{2}{*}{ SARPRAS } & \multicolumn{2}{|c|}{ PERUBAHAN } \\
\cline { 2 - 3 } & \multicolumn{1}{|c|}{ SEBELUM } & \multicolumn{1}{c|}{ SESUDAH } \\
\hline \multirow{2}{*}{$\begin{array}{l}\text { Gedung } \\
\text { UKS }\end{array}$} & $\begin{array}{l}\text { Ukuran 3 X 3 M } \\
\text { kotor, pengab cat } \\
\text { sudah lama, } \\
\text { tempat }\end{array}$ & $\begin{array}{l}\text { Sudah bersih, cat } \\
\text { baru, dan selalu } \\
\text { terbuka pintunya } \\
\text { selama jam sekolah }\end{array}$ \\
\hline
\end{tabular}

\begin{tabular}{|c|c|c|}
\hline \multirow{2}{*}{ SARPRAS } & \multicolumn{2}{|c|}{ PERUBAHAN } \\
\hline & SEBELUM & SESUDAH \\
\hline & $\begin{array}{l}\text { menyimpan } \\
\text { barang barang. }\end{array}$ & \\
\hline Mebeler & $\begin{array}{l}\text { Tidak memiliki: } \\
\text { tempat tidur dan } \\
\text { almari obat } \\
\text { (Kotak Obat } \\
\text { kecil) }\end{array}$ & $\begin{array}{l}\text { Sudah memiliki } \\
\text { tempat tidur untuk } \\
\text { pasien, almari obat } \\
\text { (etalase kaca) dan } \\
\text { kursi }\end{array}$ \\
\hline $\begin{array}{l}\text { Obat - } \\
\text { obatan }\end{array}$ & $\begin{array}{l}\text { Dulu hanya } \\
\text { sedikit dan } \\
\text { terbatas }\end{array}$ & $\begin{array}{l}\text { Sudah lengkap seperti } \\
\text { yang ada didaftar } \\
\text { pembelian barang } \\
\text { mitra } 2\end{array}$ \\
\hline $\begin{array}{l}\text { Alat - Alat } \\
\text { Kesehatan }\end{array}$ & $\begin{array}{l}\text { Timbangan tapi } \\
\text { sudah rusak }\end{array}$ & $\begin{array}{l}\text { Ada tensi meter, } \\
\text { stetoskop, } \\
\text { termometer, meteran } \\
\text { pengukur tingga } \\
\text { badan, bidai, dll. }\end{array}$ \\
\hline SDM & $\begin{array}{l}\text { Dua tenaga } \\
\text { pengelola UKS, } \\
\text { Belum punya } \\
\text { tim dokter kecil } \\
\text { dan tim tanggap } \\
\text { darurat, juga } \\
\text { belum pernah } \\
\text { dilatih. }\end{array}$ & $\begin{array}{l}\text { Memiliki lima tenaga } \\
\text { pengelola UKS, } 10 \\
\text { siswa tim dokter kecil } \\
\text { dan tim tanggap } \\
\text { darurat, sudah dilatih. }\end{array}$ \\
\hline
\end{tabular}

\section{KESIMPULAN DAN SARAN}

\section{Kesimpulan}

1. Terjadi peningkatan pengetahuan bagi para guru dan siswa melalui kegiatan pelatihan managemen UKS berbasis inklusi, penaganan cedera dan sakit disekolah, dan pelatihan BLS peningkatan pengetahuan dari cukup menjadi sangat baik.

2. Terjadi Peningkatan keterampilan tentang pengelolaan UKS berbasis inklusi, memberikan pertolongan pertama pada cedera dan sakit disekolah, dan memberikan pertolongan bantuan hidup dasar pada kondisi kegawatdaruratan dilingkungan sekolah peningkatan pengetahuan dari cukup menjadi sangat baik.

3. Terjadi peningkatan secara kualitas dan kuantitas pelayanan UKS yaitu perbaikan fasilitas ruangan, mebeler tempat tidur pasien, almari obat, meja tulis dan kursi. Peningkatan kuantitas jenis obatan - abatan dan alat - alat kesehatan, sehingga perbaikan dalam pelayanan UKS yang lebih layak.

4. Terbit publikasi koran jawa pos radar malang pada tanggal 3 Mei 2018 Hal 12, sebagai media 


\section{informasi dan memberikan inspirasi kepada masyarakat.}

5. Poster dengan judul : Alur Prosedur Standar Pelaksanaan Tanggap Darurat Penanganan Cedera dan Kegawatdaruratan DiSekolah.

6. Terbit Surat Pencatatan Ciptaan Nomor dan Tanggal Permohonan : EC00201824541, 20 Agustus 2018, Jenis Ciptaan Poster dengan judul : Alur Prosedur Standar Pelaksanaan Tanggap Darurat Penanganan Cedera dan Kegawatdaruratan DiSekolah.

7. Modul Penaganan Cedera dan Kegawatdaruratan diSekolah sebagai media untuk proses belajar secara berkelanjutan bagi para guru dan siswa pengelola UKS berbasis inklusi

8. Modul UKS berbasis Inklusi sebagai media untuk proses belajar secara berkelanjutan bagi para guru dan siswa pengelola UKS berbasis inklusi

9. Draft Publikasi ilmiah pada jurnal ber ISSN/Prociding jurnal nasional

10.Draft Buku UKS berbasis Inklusi berISBN sebagai media untuk proses belajar secara berkelanjutan bagi para guru dan siswa pengelola UKS berbasis inklusi

\section{Saran}

1. Pendampingan lebih lanjut bagi pengelola UKS yaitu kerampilan dalam menggunakan alat - alat kesehatan diUKS untuk menunjang pemeriksaan

2. Pendampingan lebih lanjut terkait screening atau deteksi penyakit pada siswa, sehingga perlu kemampuan pengenali tanda dan gejala penyakit secara langsung pada siswa.
3. Pendampingan lebih lanjut dalam menyelenggarakan secara langsung kegiatan UKS dalam memberikan layanan siswa yang sakit, mulai dari pencatatan, pemeriksaan, mendiagnosa dan memutuskan perlu ditangani UKS atau dirujuk.

4. Advokasi pada pemangku kepentingan UKS untuk membuat kebijakan yang berwawasan kesehatan.

\section{REFERENSI}

Aken, C.V., Junger M., Verhoeven, M., Aken, G.V., Dekovic, M. Externalizing Behaviors And Minor Unintentional Injuries In Toddlers. Journal of Pediatric Psychology, 2007;32(2):230-244

Atak, N., Karaoğlu, L., Korkmaz, Y., Usubütün, S. A Household Survey: Unintentional Injury Frequency And Related Factors Among Children Under Five Years In Malatya. The Turkish Journal of Pediatrics, 2010;52:285-293

Kuschithawati, S., Magetsari, R., Nawi. Faktor Risiko Terjadinya Cedera Pada Anak Usia Sekolah Dasar. Jurnal Berita Kedokteran Masyarakat, 2007;23(3):131-141.

Peraturan Menteri Pendidikan Nasional Republik Indonesia No.70 Tahun 2009 Tentang Pendidikan Inklusif

Soetjiningsih. (2008). Pertumbuhan dan Perkembangan Anak. EGC: Jakarta. Supartini, Yupi. (2010). Ilmu Keperawatan Anak. EGC: Jakarta. 